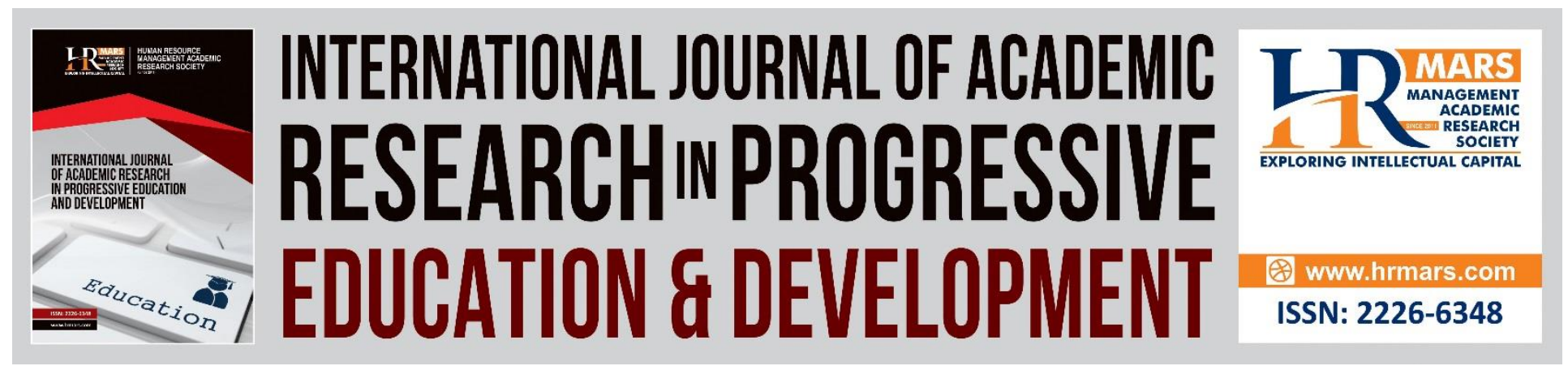

\title{
Relationship Impact of Principals' Transformational Leadership Style and Effectiveness of School as Perceived by Teacher's in Lagos State Secondary Schools, Nigeria
}

\section{Yusuf Adeola Moshood, Soaib Asimiran, Suhaida Abd. Kadir}

To Link this Article: http://dx.doi.org/10.6007/IJARPED/v9-i3/8055

DOI:10.6007/IJARPED/v9-i3/8055

Received: 10 October 2020, Revised: 09 November 2020, Accepted: 27 November 2020

Published Online: 08 December 2020

In-Text Citation: (Moshood et al., 2020)

To Cite this Article: Moshood, Y. A., Asimiran, S., \& Kadir, S. A. (2020). Relationship Impact of Principals' Transformational Leadership Style and Effectiveness of School as Perceived by Teacher's in Lagos State Secondary Schools, Nigeria. International Journal of Academic Research in Progressive Education and Development, 9(3), 160-169.

Copyright: (C) 2020 The Author(s)

Published by Human Resource Management Academic Research Society (www.hrmars.com)

This article is published under the Creative Commons Attribution (CC BY 4.0) license. Anyone may reproduce, distribute, translate and create derivative works of this article (for both commercial and non-commercial purposes), subject to full attribution to the original publication and authors. The full terms of this license may be seen at: http://creativecommons.org/licences/by/4.0/legalcode

Vol. 9(3) 2020, Pg. 160 - 169

http://hrmars.com/index.php/pages/detail/IJARPED

JOURNAL HOMEPAGE

Full Terms \& Conditions of access and use can be found at http://hrmars.com/index.php/pages/detail/publication-ethics 


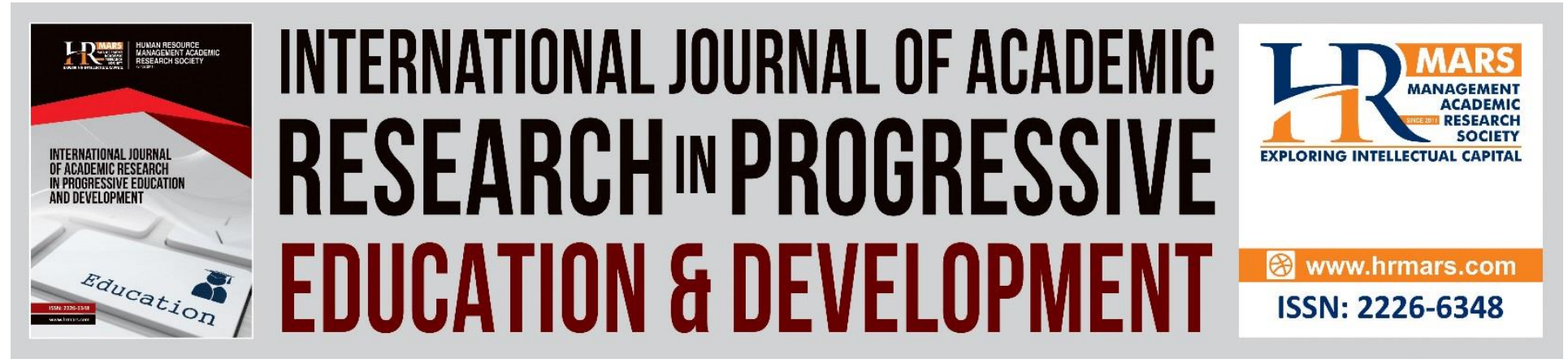

\title{
Relationship Impact of Principals' Transformational Leadership Style and Effectiveness of School as Perceived by Teacher's in Lagos State Secondary Schools, Nigeria
}

\author{
Yusuf Adeola Moshood, Soaib Asimiran, Suhaida Abd. Kadir \\ Faculty of Educational Studies, Universiti Putra Malaysia, 43400 UPM Serdang, Selangor, \\ Malaysia
}

\begin{abstract}
Practicing the transformational leadership style by school principals have shown to have a significant great impact on several studies conducted on school effectiveness. This study was aimed at exploring the relationship that exists between the school principals' transformational leadership style and school effectiveness among Secondary schools in Lagos State, Nigeria. The study also determined what level of school effectiveness and transformational leadership practice as perceived by the schoolteachers. Data were collected and completed by 372 teachers in 20 local governments. The sample size was determined using multistage sampling procedures and analyzed by using descriptive statistics and Person product-moment correlation statistical tools. The finding of the study revealed that the principal transformational leadership style and school effectiveness are positively correlated. The study further revealed that both level of school effectiveness and principal transformational leadership are at a moderate level. It is, therefore, recommended that the government through the ministry in charge of education and school administrators should increase efforts at improving school's effectiveness through constant training for Principals and teachers where more emphasis should be placed on transformational leadership style which focuses on producing excellent academic performance, developing a clear vision and mission to be the watchdog for everyone, shared school goals, supporting and encouraging teachers to perfume and excel in their profession, the high expectation for success, rewards, intellectual stimulation, modeling and culture-building that will affect and improves on the schools' outcomes and achieving of set objectives.
\end{abstract}

Keywords: Nigeria, Principals, School Effectiveness, Secondary School, Transformational Leadership. 


\section{Introduction}

Secondary school ineffectiveness has become a norm and has been a front-burner issue confronting Nigeria schools for more than two decades now, among various factors contributed to the perceived ineffectiveness of secondary schools in Nigeria includes principals' leadership styles, learning environment, teachers' quality, expectations on students' success and monitoring of students' progress (Ekundayo, 2017). Research on school effectiveness has become important to address the issue of students' mass failure in public examinations and needs to reposition and prepare secondary school leavers for the future and position them better in society. Several studies on school effectiveness had been conducted and well-established factors have been established to have a strong significant effect either directly or indirectly on students' achievements. An effective school is said to include quality Principals, teachers, students, and parents where the principal assumes a leadership role and plays a very key role in the management and functioning of the school. Lezotte (2014) mentioned the effective school to be one in which every student in a school can learn a specific curriculum regardless of factors in their family backgrounds which ordinarily have been identified as those which could prevent such students from learning.

However, school effectiveness is measured by the level of student and teachers' discipline, school climate, and students' academic achievement (Bolanle, 2013). The report shows that public school students academic performance who recently sat for West African Examination Council (WAEC) 2018 dropped to $48.10 \%$ from 56.53\% in 2017 ((NBS), 2019), this was a clear indication that the percentage of failure rate has increased by $8 \%$ which is an indication that all is not well with students' performance in the secondary schools, graduates of secondary schools have poor mastery of English language, mathematics and lack of technical skills, all these are indices that secondary schools in Nigeria is deteriorating further and is longer termed or seen to be effective compared to the past and this is attributed to the reasons why parents and even government officials who can afford to pay for expensive private education provider now seeks for quality and better education in developed nations. Furthermore, secondary schools' education has been confronting problems such as a decline in standard, examination malpractices, deteriorating facilities, cultism, and the likes as witnessed across the country. However, among several factors attributed to the school effectiveness and improvement, this study was carried strictly to find out the impact of principal's transformational leadership style on school effectiveness among other factors, the reason for this choice was based on the fact that several studies have shown that leadership has great influence and best contributor in any organization.

Transformational leaders had been regarded as not only the type that stimulates but also inspires their subordinates to both achieve the extraordinary outcome and, in the process it enhances their leadership capacity. Studies have shown that Principal transformational leadership has positively affected organizational commitments and value re-orientation among secondary schools (Ekpoh\&Asuquo, 2018). Transformational leadership style if practice by principals and teachers in secondary schools in Nigeria will affect and improve school organization (Money, Effectiveness of Transformational Leadership Style in Secondary, 2017). However, the transformational leadership style by the school principal is probably the most effective among leadership style as shown by several educational studies because of its effects on teachers' performance and school development which focuses on development changes through fostering 
group goals, providing intellectual stimulation, modeling behavior for others to follow and also individualized support. According to Hallinger (1998), studies have also indicated how the presence/absence of effective school principal, the positive attitudes of teachers, and also the positive schools' climates, can directly or otherwise affect both the school performance and student achievement (Philip Hallinger, 1998).

Furthermore, the importance of a principal transformational style of leadership in way of transforming the school to solving problems that shut out and prevent an increase in student achievement, improve in both moral support to both teachers and student and overall school effectiveness cannot be questionable. Therefore, this study was aimed to study relationship that exists between transformational leadership style and overall effectiveness of secondary schools and to determine the level of the variables.

\section{Literature Review}

\section{Transformational Leadership Style and School Effectiveness}

Research on transformational leadership styles and school effectiveness has been widely carried out by scholars in educational settings and findings suggested that transformational leadership increases student academic outcomes and school effectiveness. Findings have also shown that significant progress has been made by applying transformational leadership style to school conditions and learning outcome (Hallinger, 2011)

Transformational leadership style has been proven by many researchers as the one that inspire and encourage members of the organization to focus more on a common vision and collaborative approach which develops and builds what is called strong school culture and commitment of members (Sergiovanni, 2007). According to (Baharak et al., 2017), principal transformational leadership style was found to positively affect the overall level of school effectiveness in Malaysia's primary schools. Similarly, research conducted in Akwa Ibom State, Nigeria has shown a strong positive correltaion between transformational leadership style and organizational commitment (Ekpoh \& Asuquo, 2018). Contrarily, the study carried out by Leithwood (2006) on the impact of transformational school leadership, effects on teachers and their classroom practices, and student learning on 2,290 teachers from 655 primary school in the united kingdom indicated a significant effect of transformational leadership on teachers' classroom practices, but not much was recorded on student achievement (Kenneth Leithwood and Doris Jantzi, 2006). However, a study carried out by Bolanle (2013) shows that principals' leadership has a significant relationship with school effectiveness

Principals' transformational leadership styles have proven to be crucial in transforming both teachers' and students' academic achievement. Poor student academic performance of Lagos secondary school students in western African examinations has necessitated the need for the principal's transformational leadership knowledge which aimed at achieving better performance in the academic examination and prepare students for higher education and overall school effectiveness.

However, evidence from literature review shows that most of the studies on transformational leadership and school effectiveness were carried out mostly in developed nations and only a few studies have been done to the knowledge of the researcher in the study area have addressed this issue, In light of this, the need to fill the gap. Furthermore, the current study will either 
corroborate or oppose the earlier findings on principal transformational leadership and school effectiveness.

\section{Methodology}

Research Design

This study is a quantitative correlation research study, as the study was aimed at exploring the relationship between school effectiveness and transformational leadership style. An adapted questionnaire was used to gather data for each variable in 20 local governments. The study sample and population consisted of teachers in a public secondary school in Lagos state and the sample selected for study comprising of four hundred and five (405) teachers selected from 40 secondary schools across all the local government in Lagos state using multi-stage sampling technique to draw up the sample size in the study area. The sample sized was determined using Cochran's (1997) (Cochran, 1997) method.

A research instrument was adapted and titled "Transformational Leadership (TLQ) and School Effectiveness Questionnaire (SEQ)" was adapted and administered to the participants from the study area. The instrument consists of three sections: Section 1 measured Demographic information, sections 2 and 3 measured school effectiveness and transformational leadership respectively. The school effectiveness questionnaire had 37 items while the transformational leadership questionnaire had 39 items and participants were required to respond using a 5-point Likert scale. The TLQ and SEQ were validated by experts in the field and found to meet both face and content validity.

The reliability of the instrument was conducted and determined by conducting a Pilot study through 30 teachers to determine the reliability of the instrument. Their responses were analysed with the aid of SPSS and it provided a reliability co-efficient of 0.904 and 0.884 respectively and corrections were made based on wordings error. The data collected were analysed using statistical tool SPSS version 23 , by performing descriptive and inferential statistics to determine the level and correlation between the variables.

\section{Results}

Demographic

The result as presented in table 1 indicated that there are more male teachers than the female which shows $53.8 \%$ of the respondents were male. And, the remaining of $(46.2 \%)$ were all female.

Table 1 below also revealed that about $37.9 \%$ or 141 respondents fall into the age bracket of 25 and 30 years, followed by age group 31 to 35 years (46.0\%), 36 years and above (13.7\%), and only $9(2.4 \%)$ respondents are above 41 years of age. The result also shows that $64.5 \%$ of the respondents have academic qualification up to the level of a bachelor's degree (B.Sc. /B.Ed.)., followed by 126 respondents (33.9\%) have education qualification up to N.C.E. Certificate and just only 6 respondents (1.6\%) possessed a master's degree. In terms of working experiences, the majority of the respondents (69.1\%) admitted that they have 6-10 years of working experience. Meanwhile, $20.7 \%$ of the participants have between 2-5 years 
INTERNATIONAL JOURNAL OF ACADEMIC RESEARCH IN PROGRESSIVE EDUCATION AND DEVELOPMENT

Vol. 9, No. 3, 2020, E-ISSN: 2226-6348 @ 2020 HRMARS

of working experience. Furthermore, only (10.2\%) of the participants admitted that they have worked for than 11 years of full-time as a teacher.

Table 1: The Demographic Profile of the Respondents ( $n=372$.

\begin{tabular}{lll}
\hline Demographic Variable. & Frequency. $(\mathbf{n})$. & Percentage .(\%). \\
\hline Gender & & \\
\hline Male. & 200 & 53.8 \\
\hline Female. & 172 & 46.2 \\
\hline Age (years). & & \\
\hline 25-30 years old. & 141 & 37.9 \\
\hline 31-35 years old & 171 & 46.0 \\
\hline 36-40 years old & 51 & 13.7 \\
\hline 41-45 years old & 9 & 2.4 \\
\hline Level of Education & & \\
\hline Masters & 6 & 1.6 \\
\hline B.Sc./B.Ed. & 240 & 64.5 \\
\hline NCE Certificate & 126 & 33.9 \\
\hline Working Experience & & \\
\hline 2-5 years & 77 & 20.7 \\
\hline 6-10 years & 257 & 69.1 \\
\hline 11 years and above & 38 & 10.2 \\
\hline
\end{tabular}

\section{Teachers Perception of Level of School Effectiveness}

Table 2 below displays the result of teachers' perception of the level of secondary school effectiveness. The findings indicated that the overall sample mean was $2.9(S D=.28)$. This explains that the level of school effectiveness in secondary schools as per the teacher's point of view was at a moderate level in the state. More specifically, $100 \%$ of the whole participants perceived that school effectiveness was considered to at a moderate level as shown below.

Table 2: The Level of School Effectiveness

\begin{tabular}{|c|c|c|c|c|}
\hline Level & $\begin{array}{l}\text { Frequency } \\
\text { (n) }\end{array}$ & $\begin{array}{l}\text { Percentage } \\
\text { (\%) }\end{array}$ & Mean & $\begin{array}{l}\text { Standard } \\
\text { Deviation }\end{array}$ \\
\hline School Effectiveness & & & 2.9214 & 28776 \\
\hline $\begin{array}{lll}\text { Low } & \text { level (1.00- } \\
2.33) . & \end{array}$ & 0. & 0. & & \\
\hline $\begin{array}{l}\text { Mod. level (2.34- } \\
\text { 3.67). }\end{array}$ & 372.00 & 100.00 & & \\
\hline $\begin{array}{l}\text { High level (3.68- } \\
5.00) \text {. }\end{array}$ & 0. & 0. & & \\
\hline Total & 372.00 & 100.00 & & \\
\hline
\end{tabular}

Note: $\mathrm{n}=372$ 
Teacher's Perception of Level of Principal Transformational Leadership style.

Table 3 results revealed that the overall mean score of teachers' attitudes to the level of principal transformational leadership is $2.9(\mathrm{SD}=.33$ ) revealing that respondents were generally perceived principal transformational leadership in their school to be at a moderate level.

Table 3: Level of Principal Transformational Leadership.

\begin{tabular}{lllll}
\hline Level & $\begin{array}{l}\text { Frequency } \\
\text { (n) }\end{array}$ & $\begin{array}{l}\text { Percentage } \\
\text { (\%) }\end{array}$ & Mean & $\begin{array}{l}\text { Standard } \\
\text { Deviation }\end{array}$ \\
\hline $\begin{array}{l}\text { Transformational } \\
\text { Leadership }\end{array}$ & & & 2.9 & .33 \\
\hline Low level (1.00-2.33) & 0 & 0 & & \\
\hline $\begin{array}{l}\text { Moderate level (2.34- } \\
\text { 3.67) }\end{array}$ & & 100 & & \\
\hline High level (3.68-5.00) & 0 & 0 & & \\
\hline Total & $\mathbf{3 7 2}$ & $\mathbf{1 0 0 . 0}$ & & \\
\hline
\end{tabular}

\section{Relationship}

The Pearson Product - Moment Correlation Coefficient ( $r$ ) as shown below in Table below indicated there was a strong positive correlation of $(r=.69 ., p=.05)$ between the principal transformational leadership style and their school effectiveness.

The correlational strength was identified as high in correlation. According to Cohen (1988), the strength of the relationship between transformational leadership and the effectiveness of school was considered high.

Table 4: Pearson Correlations Coefficients of the Relationship between the Principals Transformational Leadership style and Effectiveness of school

\begin{tabular}{llll}
\hline & $\mathrm{R}$ & \multicolumn{1}{c}{$\begin{array}{l}\text { Strength of } \\
\text { the } \\
\text { Relationship. }\end{array}$} \\
\cline { 2 - 3 } & $\begin{array}{l}\text { School } \\
\text { Effectiveness. }\end{array}$ & $\begin{array}{l}\text { Transformational } \\
\text { Leadership. }\end{array}$ \\
\hline $\begin{array}{l}\text { School } \\
\text { Effectiveness. }\end{array}$ & 1.00 & 0.692 & \\
\hline
\end{tabular}

$\begin{array}{llll}\text { Transformational } & 0.692 & 1.00 & \text { High }\end{array}$

Leadership.

** Correlation is significant at the 0.01 level (2-tailed)

\section{Discussion}

This study was aimed at determining the relationship that exists between Principal transformational leadership style and overall school effectiveness in secondary schools in Lagos State, Nigeria. Through the assessment of the overall dimensions of transformational leadership styles and school effectiveness using Person correlation to measure their relationship, the results 
reviewed that the transformational leadership style has a significant positive high relationship with school effectiveness. This indicated that if mean scores of transformation leadership increase, the level of school effectiveness will be highly increased. The respondents have rated their principals to have a reasonable transformational style in transforming their followers and students.

Furthermore, the results also show that teachers perceived the level of school effectiveness and principals' transformation leadership to be at a moderate level with a mean score of 2.9 each.

The result of the study was in agreement with the research conducted by Ekpoh and Asuguo (2018) that principals' transformational leadership has a significant effect on organizational commitment and value re-orientation of teachers.

The findings of this study of the study also in line with Baharak et al., (2017), who found that headmasters practicing transformational leadership dimensions enhance the level of school effectiveness. Similarly, the results were also in line with Miskey (2013) that there was a strong positive significant relationship between school effectiveness and transformational leadership (Miskel, 2013)

The study conducted by Abass (2017) on the relationship that exists between the leadership, school culture, and their school effectiveness with teacher's empowerment among public secondary schools in northern part Zamfara State, Nigeria, revealed that there was a significant correlation between characteristics of effective school and school leaders (Dahiru, 2017).

Similarly, a study conducted by Veronica (2017) on the effectiveness of transformational leadership in Nigeria, shows that principals and teachers have good knowledge of transformation leadership styles but doubtful if the practical aspect of transforming follows and students are realized. Therefore, the result of this study indicated that for an effective school to be achieved, secondary school principals should with utmost adherence continually to transformational leadership practices which in turn improve students' performance and transforming the schools.

\section{Implications of the Study}

This study has provided an insight for the educational administrators that they need to step up and provide continuous training and engagement with the schools' principal on the practicing of transformational leadership styles and provides templates and guidelines that improve school effectiveness across the state.

\section{Conclusion}

According to the finding of the study, practicing transformation leadership by school principals has shown a great positive effect on school improvement and development. The transformational leadership style as an important factor affecting school effectiveness should be maintained by school principals. Therefore, for schools to achieve a great level of effectiveness, school administrators and principals should improve on the leadership style of transforming their teacher's and students' outcomes towards the development of their own capacities in achieving the objectives and set goals of schools. The findings also suggested principals should increase the practice of transformation leadership dimensions through developing of shared vision, highperformance expectations, models behaviors, and building collaborative structures to improve the level of school effectiveness. 
It is also recommended that school administrators through the ministry of Education improve on the school infrastructure facilities by providing good classroom with tables and chairs, teaching materials and makes the teaching profession more attractive through provisions of good working environments and rewards that improve the efficiency and effectiveness of teachers which indirectly leads to school effectiveness. In conclusion, an increase in the level of principal transformation leadership will have a positive effect on the school's effectiveness by establishing strong and collaborative efforts with teachers and parents in monitoring students' performance and setting a high expectation for success.

The contribution of this research shows that the level of school effectiveness in Lagos state secondary school is at a moderate level by practicing transformational leadership dimensions. The finding is similar to Leithwod (1995) study that practicing transformational leadership by formulating a vision is a key mechanism for achieving integration or alignment of activities which increases effectiveness within the school.

The established positive and significant relationship between the variables provided support for the social system theory which states that school is a social system as it contains characteristics such as input, process, output, and the activities of the members are with the primary aim of achieving the same goal. Another implication for this study to the literature of school effectiveness is providing a model that can be used in order to increase understanding of the antecedents of transformational leadership style among secondary school in Lagos.

\section{References}

Bolanle, A. O. (2013). Principals' Leadership Skills and School Effectiveness: The Case of South Western Nigeria. World Journal of Education.

Cochran. (1997). An empirical investigation into the validity of servqual in the public sector. 1997: spaef.

Cohen, J. (1988). Statistical Power Analysis. Lawrence erlbaum associates, publishers.

Dahiru, A. S. (2017). Relationship between entrepreneurial leadership practice, school culture, and school effectiveness with teacher empowerment in secondary schools of Zamfara State, Nigeria

Ekundayo, I. A. (2017). Factors Determining the Effectiveness of. The Anthropologist, 34

Hallinger, P. (2011). Leadership for learning: lessons from 40 years of empirical research. Journal of Educational

Maxwell, J. C. (2013). The Value of a Team.

Miskel, W. K. (2013). EDUCATIONAL ADMINISTRATION Theory, Research, and Practice. McGrawHill, a business unit of The McGraw-Hill Companies, Inc., 1221 Avenue of the Americas, New York, NY 10020

Money, V. O. (2017). Effectiveness of Transformational Leadership Style in Secondary. Journal of Education and Practice www.iiste.org.

Lezotte, L. W. (2014). Correlates of Effective Schools.

Philip Hallinger, R. H. (1998). 'Explorig the Principal's Contributio $n$ to School Effectiveness: 19801995', School Effectiveness and School Improvement, 9: 2, $157-191$. 'Exploring the 
INTERNATIONAL JOURNAL OF ACADEMIC RESEARCH IN PROGRESSIVE EDUCATION AND

DEVELOPMENT

Vol. 9, No. 3, 2020, E-ISSN: $2226-6348 @ 2020$ HRMARS

Principal's Contribution to School Effectiveness: 1980-1995', School Effectiveness and School Improvement, 9: 2, 157 - 191.

Sergiovanni, T. J. (2007). RETHINKING LEADERSHIP: a collection of articles. Thousand Oaks, Calif. Corwin Press, [2007] 2 authors:

Ekpoh \& Asuquo. (2018). PRINCIPALS' TRANSFORMATIONAL LEADERSHIP PRACTICES AS. International Journal of Education, Learning, and Development

Baharak, T., Ramli, B., Aminuddin, H., \& Asimiran. (2017). The Relationship between Transformational Leadership and Overall School Effectiveness in Primary Schools, Selangor, Malaysia Based on Teachers Perception 